University of Massachusetts Amherst

ScholarWorks@UMass Amherst

1998

\title{
Determination of acetaminophen by flow injection with on-line chemical derivatization: Investigations using visible and FTIR spectrophotometry
}

ML Ramos

JF Tyson

DJ Curran

Follow this and additional works at: https://scholarworks.umass.edu/chem_faculty_pubs

\section{Recommended Citation}

Ramos, ML; Tyson, JF; and Curran, DJ, "Determination of acetaminophen by flow injection with on-line chemical derivatization: Investigations using visible and FTIR spectrophotometry" (1998). ANALYTICA CHIMICA ACTA. 1065.

Retrieved from https://scholarworks.umass.edu/chem_faculty_pubs/1065 


\title{
Determination of acetaminophen by flow injection with on-line chemical derivatization: Investigations using visible and FTIR spectrophotometry
}

\author{
Maiella L. Ramos ${ }^{1}$, Julian F. Tyson, David J. Curran* \\ Department of Chemistry, University of Massachusetts, Amherst, MA 01003-4510, USA
}

Received 5 November 1997; accepted 22 January 1998

\begin{abstract}
A new FI/FTIR method for the determination of acetaminophen (paracetamol, $N$-acetyl-p-aminophenol) involving on-line reaction is described. The proposed method is based on the alkaline hydrolysis of the analyte to produce $p$-aminophenol and its oxidation reaction with potassium ferricyanide to produce $p$-benzoquinone-monoimine which eventually oxidizes to form $p$ benzoquinone. The chemistry of the reaction was studied both, in the visible and IR regions of the spectrum and the method has been developed by the application of flow-injection methodology. The reaction was carried out in aqueous media and at room temperature. The micro-flow version of the CIRCLE ${ }^{\circledR}$ IR accessory, which is compatible with aqueous solutions, was used. Measurements were carried out at the $\mathrm{OH}$-phenolic deformation $\left(1274.1 \mathrm{~cm}^{-1}\right)$ and the aromatic ring mode $\left(1498.2 \mathrm{~cm}^{-1}\right)$ infrared vibrations for the hydrolysis product, $p$-aminophenol. The method was applied to the determination of acetaminophen in commercial tablets, and mean detection values of 512 and $491 \mathrm{mg}$ were found at 1274.1 and $1498.2 \mathrm{~cm}^{-1}$, respectively.
\end{abstract}

Keywords: Flow injection analysis/Fourier transform infrared spectroscopy (FIA/FTIR); On-line reactions; Derivatization; Acetaminophen

\section{Introduction}

There is a sustained interest in the development of simple and reliable methods for the determination of the active ingredients in pharmaceutical preparations. Not only are analyses performed in support of the production of such preparations but large numbers of dissolution studies are routinely performed to evaluate the kinetics of release of the drug species.

\footnotetext{
*Corresponding author.

${ }^{1}$ Present address: Department of Physics and Chemistry, University of Puerto Rico-Arecibo, PO Box 4010, Arecibo P.R. 00613-4010.
}

Although direct UV absorption spectrometry is a frequent choice for the instrumental technique in such methods, there are some analyses, such as acetaminophen, for which methodology is still being developed. A survey of the literature indicates that over the past 20 years in excess of 20 papers have been published describing the determination of acetaminophen by a variety of methods, none of which included direct UV absorption. Several analytical procedures for its determination have been reported, including its assay in drug formulations. These include titrimetry [1], fluorimetry [2], colorimetry based upon nitration [3,4], oxidation [5,6] and diazo coupling [7,8], chromato- 
graphy [9-13], and spectrophotometry [14-19]. In addition, electrochemical detection with liquid chromatography [20-24] and flow injection (FI) [25-27] has been applied for the determination of acetaminophen in both, pharmaceutical preparations and in body fluids.

As direct UV absorption is subject to interference from scatter from insoluble excipient particles and, together with visible absorption, is susceptible to spectral interference from unresolved, overlapping features in the spectra of other sample components or reagents, we wished to investigate the possible role for FTIR absorption spectrometry in such analyses.

The starting point for the investigations was the development of a flow-injection method for the determination of acetaminophen in which (a) direct UV absorption was used or (b) an on-line reaction product was monitored. Flow-injection (FI) methodology for systems involving on-line chemical reactions has been applied using UV-visible spectrophotometry [28-30]. An FI method was described by Stewart et al. [28] for the determination of acetaminophen based on its oxidation with 2-iodylbenzoate in acid medium to produce a colored product, $N$-acetyl- $p$-benzoquinonimine, which was monitored at $445 \mathrm{~nm}$. Other FI spectrophotometric methods [29,30] were based on the oxidation of acetaminophen with potassium ferricyanide and subsequent reaction with phenol at elevated temperatures in aqueous ammoniacal solution. In the second of these two reports [30], a method which used an ionic-exchange column to retain the potassium ferricyanide as an immobilized reagent was described. The reaction with phenol occurred at $80^{\circ} \mathrm{C}$. The oxidation product was thought to be $N$-acetyl-pbenzoquinonimine, which reacted with phenol to produce a blue compound, $N$-( $p$-hydroxyphenyl)- $p$-benzoquinonimine which was monitored at $630 \mathrm{~nm}$. Martínez Calatayud et al. [29] reported that no reaction occurred when the ammonia used was replaced by sodium hydroxide.

Work coupling FI methodology and Fourier transform infrared (FTIR) spectrometry first appeared about a decade ago. The earliest publication reported the determination of aqueous solutions of dioctyl sulfosuccinate using the cylindrical internal reflectance cell for liquid evaluation $\left(\right.$ CIRCLE $\left.^{\circledR}\right)$ as the detector cell [31]. Subsequent papers have reported on both aqueous [32-35] and organic based systems [36-43].

The application of the combined technique for quantitative determinations with the use of suitable flow cells to obtain information from transient IR signals has demonstrated its capability for the following:

1. the accurate measurement of the baseline and the exact determination of the absorbance maximum [44];

2. the simultaneous determination of various compounds in the same sample $[38,43]$;

3. pharmaceutical analysis $[31,32,39]$;

4. determination of organic compounds by the use of FTIR derivative spectrometry [41,43-45]; and

5. the quantitative determination of glucose and urea in complex matrices [33-35].

The analysis of aqueous solutions by IR spectrometry is usually accomplished by attenuated total reflectance (ATR). The mode of operation of the CIRCLE $^{\circledR}$ accessory is based on the ATR technique. The FI/FTIR technique coupled with the CIRCLE ${ }^{\mathbb{R}}$ accessory provides a potential combination for rapidly analyzing and quantifying pharmaceutical samples in aqueous solution. The use of the micro-version CIR$\mathrm{CLE}^{\circledR}$ for aqueous FI with FTIR detection has been reported [31,32]. Optimization of a basic FI-FTIR system using the CIRCLE ${ }^{\circledR}$ has been reported for the determination of acetaminophen in aqueous solutions [46]. The accessory has also been applied as a flow detector for chromatographic systems with FTIR detection [47]. An ultramicro cylindrical internalreflectance cell was designed to fit on the stage of an IR-PLAN infrared microscope [48]. All of these papers have reported on the use of infrared (IR) spectrometry for monitoring FI transients, however none of these describe applications involving on-line chemical derivatization.

In our studies of the UV and visible spectrophotometric determination of acetaminophen, positive interferences were encountered which were overcome by using the chemistry of the visible absorption method and adapting it for monitoring in the IR region. This paper, therefore, presents an FI procedure using FTIR of aqueous solutions in which an on-line reaction product is monitored. Using an attenuated 
total-internal reflectance flow cell the new FI/FTIR method was developed to follow the alkaline hydrolysis of acetamineophen with sodium hydroxide followed by the oxidation reaction of the hydrolysis product with potassium ferricyanide in aqueous media. This oxidation reaction was carried out at room temperature. There was no need for the oxidative coupling reaction with phenol at elevated temperature. The FI method is fast and simple, and was evaluated by application to the determination of acetaminophen in a commercial formulation.

\section{Experimental}

\subsection{Apparatus}

Infrared spectra were obtained with a Mattson Cygnus 100 Fourier Transform Infrared (FTIR) spectrometer (ATI Instruments, Madison, WI) equipped with a photoconductive narrow-band mercury-cadmium-telluride detector $\left(700 \mathrm{~cm}^{-1}\right.$ cutoff $)$. The spectrometer was controlled by a Dell Model 486D/33 computer which was interfaced with the Mattson Galaxy 7020A on-board electronics. The software package time-evolved kinetics operations (ATI, Madison, WI) was used for data collection, processing and analysis. The detector infrared cell used was the micro-CIRCLE ${ }^{\circledR}$ accessory (Spectra-Tech). It is a stainless steel bodied $25 \mu \mathrm{l}$ flow cell equipped with a cylindrical, zinc selenide, internal reflection element. The cell has twelve internal reflections.

A Hewlett-Packard 8452A UV-VIS diode array spectrophotometer, with a response time of $0.2 \mathrm{~s}$, equipped with an $18 \mu \mathrm{l}$ volume flow cell with a
$1 \mathrm{~cm}$ path length (Pye Unicam) was used for the absorbance measurements. Acquisition of absorbance-time data for FI peaks was done using Hewlett-Packard kinetics software. Data were transferred to DOS format by using the HP-Copy program. Macintosh software including Apple File Exchange (Apple) and Microsoft Excel Version 4.0 (Microsoft Corp.) were used for data evaluation. Statistical calculations were performed with Statview $\mathrm{SE}+$ Graphics (Abacus Concepts).

A schematic diagram of the FI system is shown in Fig. 1. It consisted of two Ismatec MS Reglo variablespeed peristaltic pumps (Ismatec SA, Switzerland), two six-port Teflon rotary injector valves (Omnifit, New York, NY), and a mixing 'Tee' as the confluence point. The two-channel manifolds were built from $0.8 \mathrm{~mm}$ i.d. Teflon tubing (Omnifit, New York, $\mathrm{NY}$ ). A $2 \mathrm{~m}$ reaction coil ( $0.8 \mathrm{~mm}$ i.d.) was connected immediately after the mixing confluence point.

\subsection{Reagents}

All solutions used in these experiments were prepared in doubly distilled deionized $18 \mathrm{M} \Omega$ Epure water (Barnstead, Dubuque, IA). Acetaminophen (Sigma, St. Louis, MO) was obtained in its crystalline form. A stock solution of $0.01 \mathrm{M}$ acetaminophen was prepared by dissolving $0.756 \mathrm{~g}$ in a $500 \mathrm{ml}$ volumetric flask. A $0.5 \mathrm{mM}$ acetaminophen solution was prepared from a $5 \mathrm{ml}$ aliquot of a $0.01 \mathrm{M}$ stock solution and dilution to $100 \mathrm{ml}$. Potassium ferricyanide $\left(\mathrm{K}_{3} \mathrm{Fe}(\mathrm{CN})_{6}\right)$ and sodium hydroxide $(\mathrm{NaOH})$ were Fisher ACS certified reagents. Stock solutions of $0.05 \mathrm{M} \mathrm{K}_{3} \mathrm{Fe}(\mathrm{CN})_{6}$ and $1 \mathrm{M} \mathrm{NaOH}$ were prepared by dissolving $8.2317 \mathrm{~g}$ and $20.00 \mathrm{~g}$, respectively in

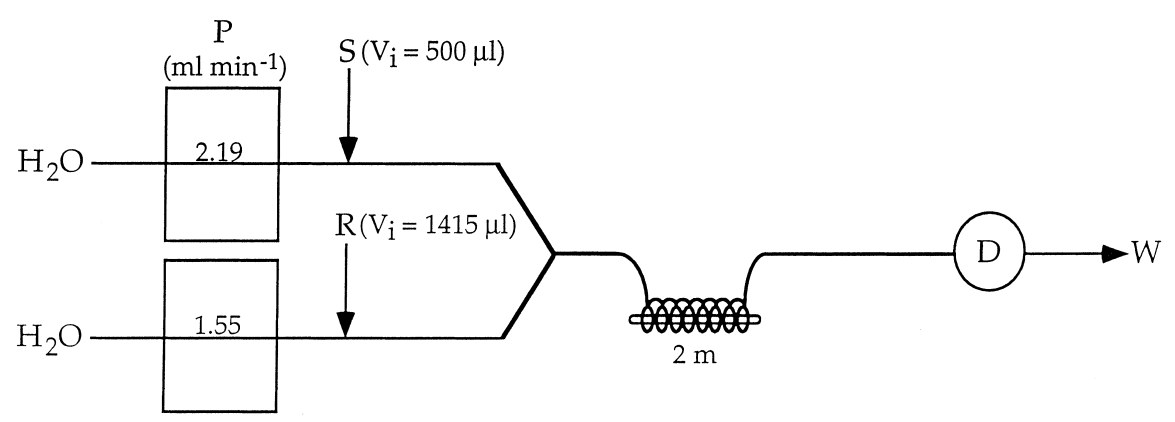

Fig. 1. FI manifold used for the on-line chemical reaction of acetaminophen where both the sample and the reagent are being injected into water as the carrier stream. 
water and diluting to $500 \mathrm{ml}$. A $0.015 \mathrm{M} \mathrm{K}_{3} \mathrm{Fe}(\mathrm{CN})_{6}$ solution in $0.5 \mathrm{M}$ sodium hydroxide solution was used as the reagent.

\subsection{Procedure}

Before starting the FI/FTIR experiments, a spectrum of the empty cell was obtained for those cases where it was necessary to subtract the sample spectra from a reference spectrum. The infrared spectra were acquired in the continuous mode. After the carrier stream of water was introduced into the cell, its spectrum was obtained against the background spectrum that previously had been taken of the empty cell, using 32 scans. All spectra were acquired at a resolution of $8 \mathrm{~cm}^{-1}$ and a mirror velocity of $3.2 \mathrm{~cm} \mathrm{~s}^{-1}$ $(50 \mathrm{KHz})$. A triangular apodization was used in all studies.

After scanning the carrier for $1 \mathrm{~s}$, both sample $\left(V_{\mathrm{i}}=500 \mu \mathrm{l}\right)$ and reagent $\left(V_{\mathrm{i}}=1415 \mu \mathrm{l}\right)$ solutions were introduced by manual operation of the injection valves into the aqueous carrier streams flowing at 2.19 and $1.55 \mathrm{ml} \mathrm{min}{ }^{-1}$, respectively. These solutions were merged and reacted in a $2 \mathrm{~m}$ reaction coil at room temperature before entering the micro-CIRCLE ${ }^{\mathbb{R}}$ accessory. The TKO software allowed rapid collection of a total of 30 interferograms with 12 scans/spectrum collected every $2.27 \mathrm{~s}$.

After the data collection was terminated, the two valves were rapidly switched to the load position allowing only water to continuously flow through the cell keeping the zinc selenide crystal clean. Each interferogram was transformed and ratioed against the background spectrum by using the batch-fast Fouriertransform. There are two ways to process the data: (1) direct ratioing of sample spectra against water as the background, or (2) subtraction of a water reference spectrum, obtained vs. the empty cell as the background, from sample spectra. A macroprogram was written allowing the FTIR subtracted spectra to be obtained and stored. This program was also developed to obtain the corrected peak-height absorbance values, taking into account the selected baseline and the exact position of the absorbance maximum. The kinetics software contained the time-evolved analysis program used for data display and analysis. To obtain the absorbance-time profiles, ASCII files were created at the respective wave numbers and transferred to
Microsoft Excel for Macintosh. A three-point smoothing procedure was applied to the absorbance data.

Data for FI experiments in the visible region were recorded with the spectrophotometer set at $476 \mathrm{~nm}$. FI profiles (absorbance vs.time) of the product were obtained by subtraction of the reagent contribution to the total absorbance. Peak-height absorbance was used for quantification.

Four tablets were individually weighed and each placed in $150 \mathrm{ml}$ of warm water $\left(\sim 60^{\circ} \mathrm{C}\right)$, and allowed to dissolve in an ultrasonic water bath for a fixed time. The time for the first tablet was $5 \mathrm{~min}$, the second $15 \mathrm{~min}$, the third $30 \mathrm{~min}$, and the fourth $60 \mathrm{~min}$. After the dissolution period, the insoluble mass was filtered by suction through a Whatman No. 1 filter-paper, which was then washed with water. The filtrate and washings were transferred into a $500 \mathrm{ml}$ calibrated flask and diluted to volume with water. For the infrared experiments these solutions were injected as samples into the water-carrier stream and for the visible spectrometric experiments the respective solutions were diluted one part to 99 parts with water.

\subsection{Method development}

The initial work was carried out using the method described by Martínez Calatayud et al. [29] in which acetaminophen was oxidized with potassium ferricyanide and the product reacted with phenol at elevated temperature in aqueous ammoniacal solution. Batch, rather than flow experiments were performed by observing the development of the colors obtained with the respective reactions when $\mathrm{NaOH}$ was used rather than the slightly basic ammoniacal solution. It was found that there was no need for elevated temperatures when using sodium hydroxide. It was concluded that only the first oxidation step with potassium ferricyanide was required as visual observations from the batch experiments indicated that it was a faster reaction under more alkaline conditions.

Based on these batch experiments, several FI parameters were studied including manifold design, concentration of sodium hydroxide, reaction coil length and injection volumes. The first experiments were carried out using an FI manifold which included two channels to transport sodium hydroxide and potassium ferricyanide separately. This flow system was then modified by putting the potassium ferricya- 
nide and sodium hydroxide reagents in the same solution and injecting the reagent into an aqueous carrier stream. It was observed that the color of the reaction solution was dependent on the concentration of $\mathrm{NaOH}$. The concentration range of $\mathrm{NaOH}$ studied was from $0.008-1 \mathrm{M}$. Injection loop volumes of sample and reagent were varied as a compromise in order to obtain excess reagent over sample concentration while achieving a lower dispersion coefficient.

\section{Results and discussion}

The chemical reaction is seen as consisting of two steps. The first step is based on the basic hydrolysis of acetaminophen to produce $p$-aminophenol, and the second one involves the oxidation reaction with potassium ferricyanide to produce $p$-benzoquinonemonoimine, an intermediate product of acetaminophen oxidation. The orange-red species which had a wavelength of maximum absorbance of $476 \mathrm{~nm}$ was believed to be the imine intermediate. The reaction scheme is shown in Fig. 2. It is believed that the final product of the oxidation reaction is $p$-benzoquinone. It has been reported [49] that when $p$-aminophenol is oxidized in alkaline solution, it yields a benzoquino- nemonoimine which reacts at the free para position of phenols to produce a blue indophenol dye which could be monitored at $630 \mathrm{~nm}$.

FI spectrophotometric results indicated that the reaction proceeds rapidly in $\mathrm{NaOH}$ at room temperature, The concentration of $\mathrm{NaOH}$ is an important parameter to control because of its effect upon the chemistry of the acetaminophen oxidation with potassium ferricyanide, and the product stability. The optimum value was found to be $0.5 \mathrm{M}$. In the presence of the oxidizing reagent, the orange-red color developed very rapidly in the time frame of the FI experiment.

Preliminary tests on the FI manifold (in which the sodium hydroxide and potassium ferricyanide were transported separately) revealed that the second step in the chemical reaction was occurring as a consequence of injecting the sample directly into one of the reagents $(\mathrm{NaOH})$ resulting in an excess of sample over the reagent and the formation of doublet peaks showed insufficient mixing of sample and reagent. As the continuous flow of the reagent solution could damage optical material of the ATR infrared cell, further changes were made to produce the manifold shown in Fig. 1. A 2 m reaction coil was used throughout the experiments and injection volumes of sample $(500 \mu \mathrm{l})$ and reagent $(1415 \mu \mathrm{l})$ were selected as the<smiles></smiles><smiles>N=C1C=CC(=O)C=C1</smiles><smiles>O=C1C=CC(=O)C=C1</smiles>

p-benzoquinonemonoimine

p-benzoquinone

Fig. 2. Hydrolysis and oxidation reactions of acetaminophen with sodium hydroxide and potassium ferricyanide in aqueous media. 
most appropriate to obtain the least dispersion. The dispersion coefficient was calculated as the ratio of the absorbance of the steady-state signal at $420 \mathrm{~nm}$ to that of an injected solution of $0.001 \mathrm{M} \mathrm{K}_{3} \mathrm{Fe}(\mathrm{CN})_{6}$, and was 1.84 .

From the IR spectral data, the region between 2000$1000 \mathrm{~cm}^{-1}$ was selected for study because water has a broad band which has very strong absorption in the $3700-3100 \mathrm{~cm}^{-1}$ region [50]. Spectral subtraction is meaningless in regions of total absorption and, therefore, direct ratioing of spectra against the water background was used. Infrared spectra of the sample obtained before and after the reaction are shown in Fig. 3. The major bands identified in the spectrum of acetaminophen (Fig. 3(a)) were the carbonyl vibration at $1637.2 \mathrm{~cm}^{-1}$, the aromatic ring vibration at $1517.5 \mathrm{~cm}^{-1}$ and the $\mathrm{OH}$ deformation-C-O stretch at $1243.2 \mathrm{~cm}^{-1}$. Other bands included the $\mathrm{H}_{3} \mathrm{C}-$ $\mathrm{C}=\mathrm{O} \quad$ stretching $\quad\left(1378.4 \mathrm{~cm}^{-1}\right), \quad \mathrm{NH}$ bending $\left(1447.9 \mathrm{~cm}^{-1}\right)$ and $\mathrm{C}-\mathrm{NH}$ vibration $\left(1552.2 \mathrm{~cm}^{-1}\right)$. The spectrum taken after the reaction (Fig. 3(b)) exhibited dominant features in the triple bond region at $2039.0 \mathrm{~cm}^{-1}(\mathrm{CN})$, and in the fingerprint region at $1498.2 \mathrm{~cm}^{-1}$ (aromatic) and $1274.1 \mathrm{~cm}^{-1}$ (OH-phenolic deformation) assigned to ferrocyanide and $p$ aminophenol, respectively. This spectrum also showed infrared bands in the double-bond region at 1683.6, $1664.3,1594.7$ and $1544.5 \mathrm{~cm}^{-1}$ that correspond to mixed ring modes which could be assigned to the oxidized species, $p$-benzoquinonemonoimine (see Fig. 2). The first two bands could arise from Fermiresonance interaction as suggested by Becker, et al. [51] in a detailed study of the infrared spectrum of $p$-benzoquinone.

IR bands in the $1550-1150 \mathrm{~cm}^{-1}$ region are shown in Fig. 4. The vibrations at 1517.5 and $1243.2 \mathrm{~cm}^{-1}$ (Fig. 4(a)) were assigned to the sample, and those given in Fig. 4(b) have been assigned to the hydrolysis product, $p$-aminophenol (1498.2 and $\left.1274.1 \mathrm{~cm}^{-1}\right)$. The FI/FTIR spectra presented in Fig. 5 were obtained by monitoring the reaction after the injection of a $50 \mathrm{mM}$ acetaminophen solution. The spectral features of products as a result of the hydrolysis and oxidation reactions change significantly with time as indicated in Fig. 5. As there were no bands associated with acetaminophen, it is concluded that the hydrolysis reaction of acetaminophen with sodium hydroxide, to form $p$-aminophenol, has gone to completion in the time frame of the experiment. On the other hand, it appeared that the oxidation reaction of $p$-aminophenol to produce $p$-benzoquinone and ferrocyanide is not instantaneous as the $p$-aminophenol and ferrocyanide

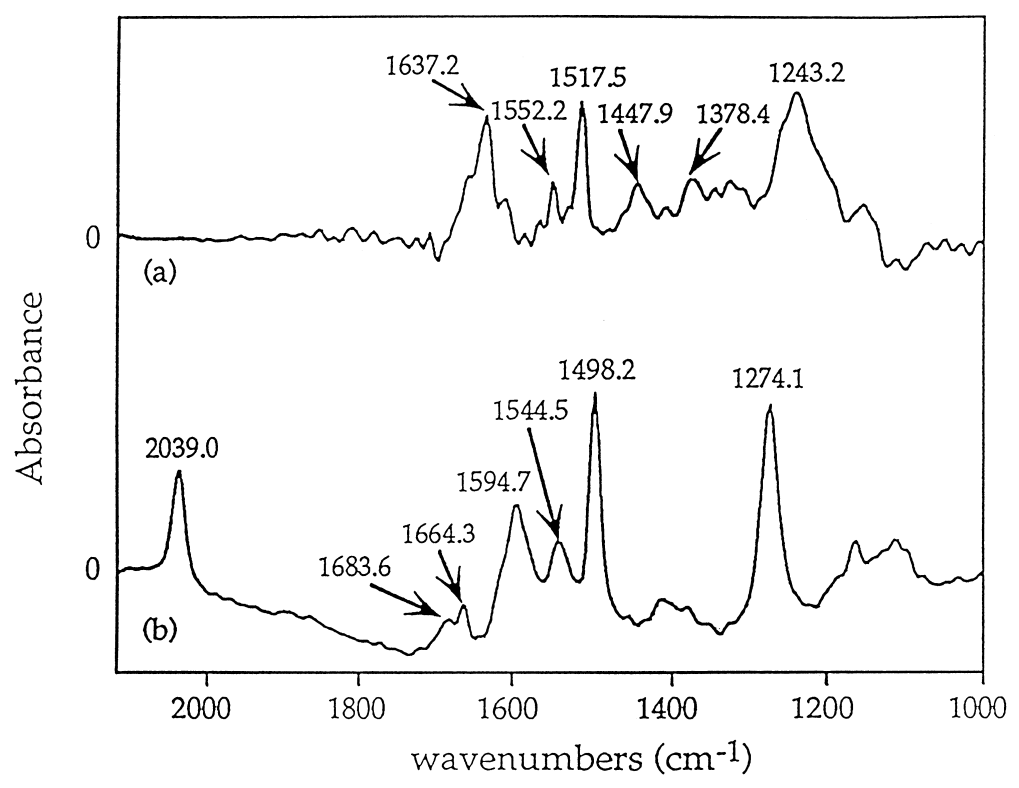

Fig. 3. FI/FTIR spectra of a $50 \mathrm{mM}$ acetaminophen aqueous solution (a) before and (b) after the reaction. 


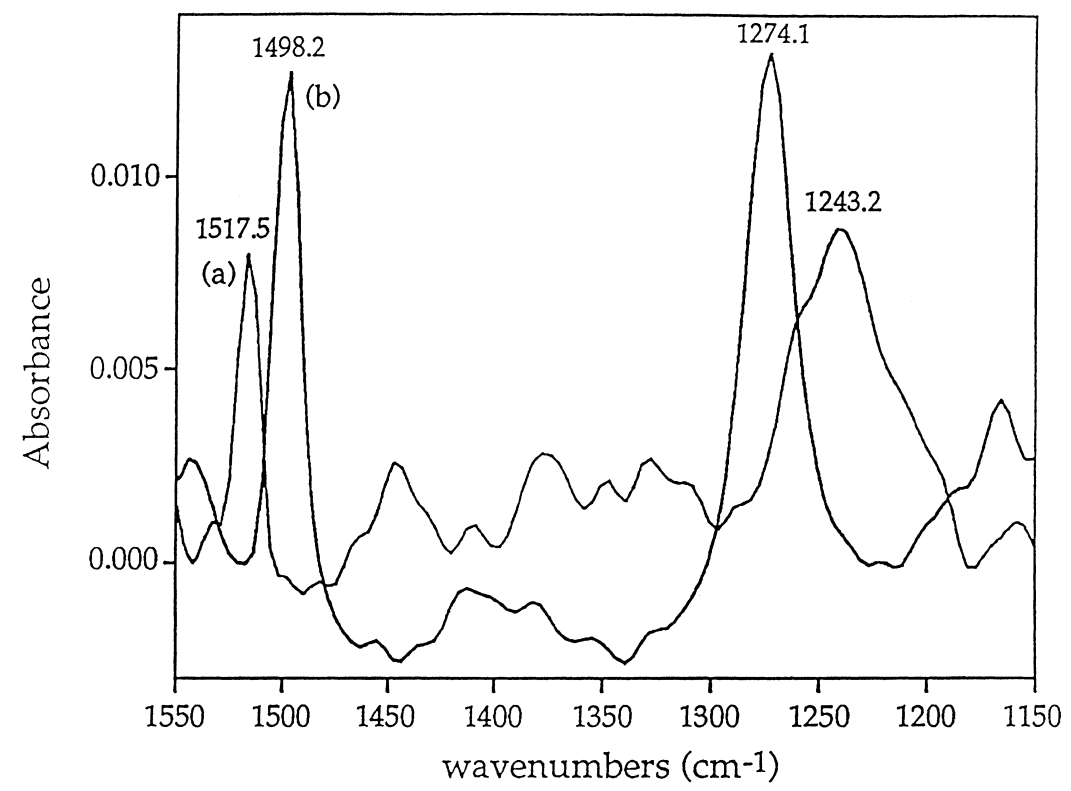

Fig. 4. FI/FTIR overlay spectra of (a) sample and (b) product taken at a data collection time of $21.47 \mathrm{~s}$ (extended region: $1550-1150.0 \mathrm{~cm}^{-1}$; [acetaminophen] $=50 \mathrm{mM}$ ).

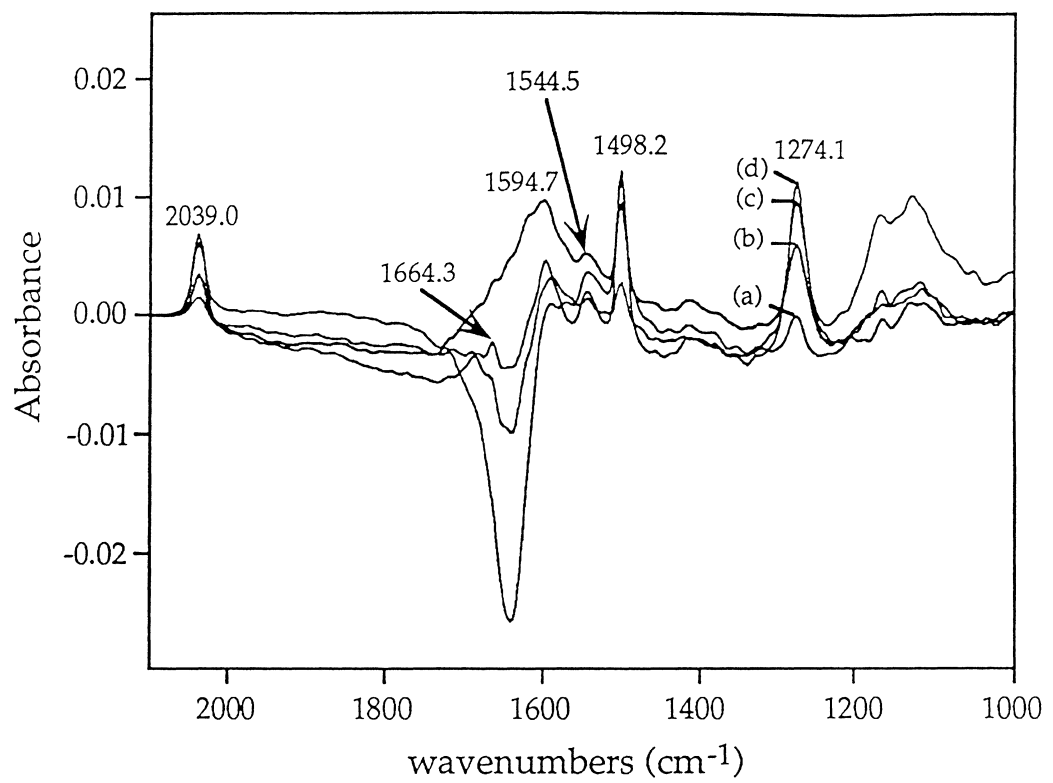

Fig. 5. FI/FTIR spectra showing the product formation from a $50 \mathrm{mM}$ acetaminophen solution at (a) $14.31 \mathrm{~s}$, (b) $16.70 \mathrm{~s}$, (c) $19.08 \mathrm{~s}$, and (d) $21.47 \mathrm{~s}$. FTIR kinetics data: one run $=>30$ spectra $(0 \mathrm{~s}$ to $68.24 \mathrm{~s})$; collection time every $2.27 \mathrm{~s}$.

species coexist (see Fig. 5). However, complete reaction is not a prerequisite for an FI method. From the spectra shown in Fig. 5, the infrared band at $1274.1 \mathrm{~cm}^{-1}$ assigned to $p$-aminophenol appeared to be a good band for quantification for two reasons: it has a well-defined baseline and it is a well-resolved band. The variation in intensities for this vibration shown in the time frame from (a) $14.31 \mathrm{~s}$ to (d) $21.47 \mathrm{~s}$ 


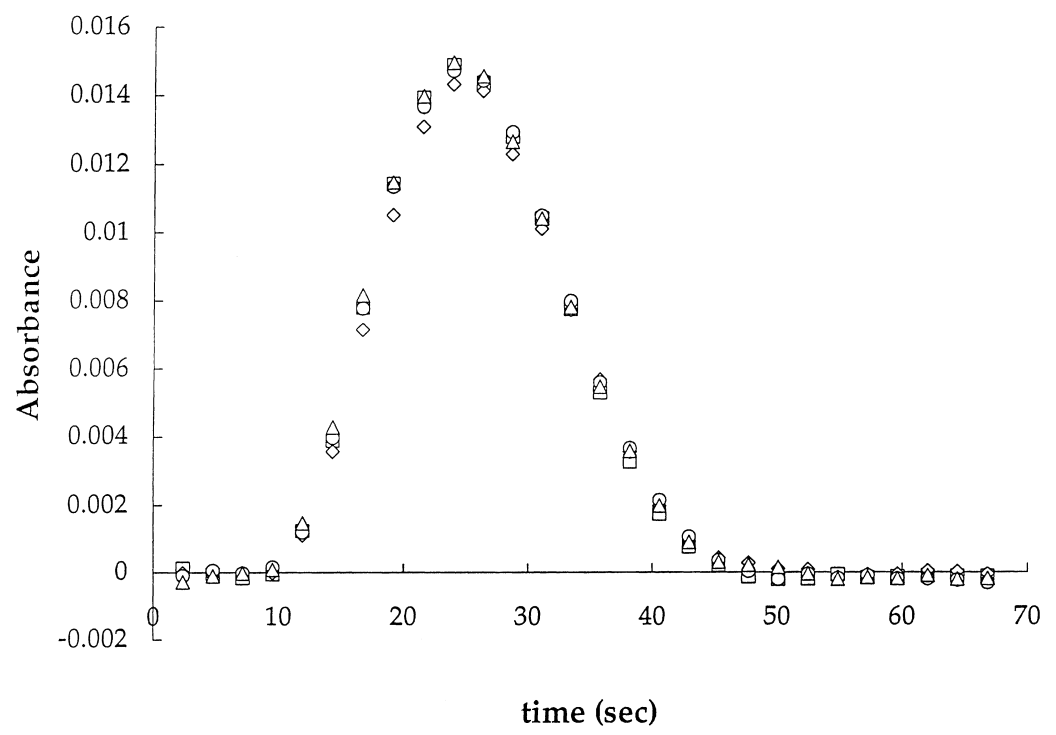

Fig. 6. Smoothed FI profile of the product, $p$-aminophenol for the $\mathrm{OH}-$ phenolic deformation band at $1274.1 \mathrm{~cm}^{-1}$.

is clearly illustrated in the rising portion of the smoothed FIA profile given in Fig. 6. The relative standard deviation for a $50 \mathrm{mM}$ sample solution was $1.9 \%(n=4)$.

It was of interest to investigate working curves obtained for both the FI/visible and the FI/FTIR approaches. Spectrophotometric determination of acetaminophen at $476 \mathrm{~nm}$ yielded a working curve with a slope of $0.6787 \mathrm{mM}$, an intercept of $5.1 \times 10^{-3}$ and a correlation coefficient of $0.998_{9}$. The concentration range was from $0.048 \mathrm{mM}$ to $0.96 \mathrm{mM}$. Results of determinations of acetaminophen in tablets of a commercial formulation including standard deviations and $95 \%$ confidence intervals are given in Table 1. The $95 \%$ confidence limits were calculated from the formulas found in Miller and Miller [52]. Different dissolution times (as described earlier) were used to see if more acetaminophen dissolved at longer times. Statistically, it was found that there was no significant difference between the first two dissolution times but a difference was found when comparing the amount of acetaminophen at $5 \mathrm{~min}$ with that at a longer time (30 $\mathrm{min}$ or $60 \mathrm{~min}$ ). However, a variable washing time was used in these experiments, hence a strict control of this variable was not maintained. In view of the nominal value of $500 \mathrm{mg}$ of acetaminophen per tablet, the results obtained from the FI/VIS experiments appear to have a significant positive error.
Table 1

Results of acetaminophen tablet analysis at different dissolution times

\begin{tabular}{lll}
\hline $\begin{array}{l}\text { Dissolution } \\
\text { time }(\mathrm{min})\end{array}$ & \multicolumn{2}{l}{ Amount $^{\text {a }}$ found $(\mathrm{mg})$} \\
\cline { 2 - 3 } & \multicolumn{2}{l}{ wavelength $=476 \mathrm{~nm}$} \\
\cline { 2 - 3 } & standard deviation & $95 \%$ confidence interval \\
\hline 5 & $528 \pm 8$ & $528 \pm 22$ \\
15 & $551 \pm 6$ & $551 \pm 19$ \\
30 & $591 \pm 7$ & $591 \pm 19$ \\
60 & $594 \pm 3$ & $594 \pm 19$ \\
\hline
\end{tabular}

${ }^{a}$ Nominal content given by the manufacturer is $500 \mathrm{mg}$ per tablet.

Calibration results obtained using the FI/FTIR method and working at wavelengths for both the sample and the product are shown in Table 2. The working curve was linear in the $0.5-50 \mathrm{mM}$ acetaminophen concentration range. Statistical data were obtained with the Statview SE+Graphics (BrainPower) software. For acetaminophen, quantification was carried out at the aromatic ring band maximum $\left(1517.5 \mathrm{~cm}^{-1}\right)$ as it does not suffer from interference by the solvent. For the hydrolysis product, $p$-aminophenol, the peak height absorbances at the 1274.1 and $1498.2 \mathrm{~cm}^{-1}$ bands were used for quantification. The method using detection at $1274.1 \mathrm{~cm}^{-1}$ provided slightly better analytical sensitivity than detection at 
Table 2

Summary of quantitative results

\begin{tabular}{|c|c|c|c|}
\hline \multirow[t]{2}{*}{ Parameters and statistical data } & \multicolumn{3}{|l|}{ Detection wave number } \\
\hline & $1517.5 \mathrm{~cm}^{-1}$ (sample) & $1274.1 \mathrm{~cm}^{-1}$ (product) & $1498.2 \mathrm{~cm}^{-1}$ (product) \\
\hline Spectral baseline (in $\mathrm{cm}^{-1}$ ) & $1498.2-1536.8$ & $1239.3-1308.9$ & $1478.9-1517.5$ \\
\hline Assignment of IR band & aromatic & $\mathrm{OH}$-phenolic deformation & aromatic \\
\hline Regression equation ( $C$ in $\mathrm{mM}$ ) & $A=1.42 \times 10^{-4} C+3.36 \times 10^{-4}$ & $A=2.96 \times 10^{-4} C-2.14 \times 10^{-4}$ & $A=2.74 \times 10^{-4} C-3.09 \times 10^{-4}$ \\
\hline Correlation coefficient & $0.999_{1}$ & $0.999_{1}$ & $0.998_{8}$ \\
\hline $95 \%$ confidence limits, slope & $(1.42 \pm 0.03) \times 10^{-4}$ & $(2.96 \pm 0.04) \times 10^{-4}$ & $(2.74 \pm 0.05) \times 10^{-4}$ \\
\hline
\end{tabular}

Table 3

Results of acetaminophen tablets analysis at different dissolution times

\begin{tabular}{|c|c|c|c|c|c|c|}
\hline \multirow[b]{3}{*}{$\begin{array}{l}\text { Dissolution } \\
\text { time (min) }\end{array}$} & \multicolumn{6}{|c|}{ Amount ${ }^{a}$ found (mg) } \\
\hline & \multicolumn{2}{|c|}{$1517.5 \mathrm{~cm}^{-1}$ (sample) } & \multicolumn{2}{|c|}{$1274.1 \mathrm{~cm}^{-1}$ (product) } & \multicolumn{2}{|c|}{$1498.2 \mathrm{~cm}^{-1}$ (product) } \\
\hline & $\begin{array}{l}\text { Mean } \pm \text { Standard } \\
\text { deviation }\end{array}$ & $\begin{array}{l}95 \% \text { confidence } \\
\text { interval }\end{array}$ & $\begin{array}{l}\text { Mean } \pm \text { Standard } \\
\text { deviation }\end{array}$ & $\begin{array}{l}95 \% \text { confidence } \\
\text { interval }\end{array}$ & $\begin{array}{l}\text { Mean } \pm \text { Standard } \\
\text { deviation }\end{array}$ & $\begin{array}{l}95 \% \text { confidence } \\
\text { interval }\end{array}$ \\
\hline$\overline{5}$ & $336 \pm 21$ & $336 \pm 52$ & $505 \pm 22$ & $505 \pm 55$ & $460 \pm 29$ & $460 \pm 72$ \\
\hline 15 & $370 \pm 6$ & $370 \pm 15$ & $479 \pm 36$ & $479 \pm 89$ & $479 \pm 29$ & $479 \pm 72$ \\
\hline 30 & $434 \pm 15$ & $434 \pm 37$ & $556 \pm 10$ & $556 \pm 25$ & $489 \pm 20$ & $489 \pm 50$ \\
\hline 60 & $384 \pm 7$ & $384 \pm 17$ & $507 \pm 11$ & $507 \pm 27$ & $535 \pm 22$ & $535 \pm 55$ \\
\hline
\end{tabular}

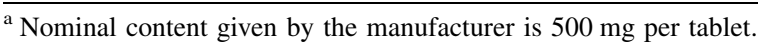

$1498.2 \mathrm{~cm}^{-1}$. Results for the determination of acetaminophen in the tablets including the standard deviations and $95 \%$ confidence intervals are given in Table 3. The $95 \%$ confidence intervals were also calculated from formulas given by Miller and Miller [52]. The FI method at $1517.6 \mathrm{~cm}^{-1}$ for the determination of acetaminophen gave low results probably because of a combination of the spectral baseline established and the fact that this band is not wellresolved. The results obtained from the FI methods at 1274.1 and $1498.2 \mathrm{~cm}^{-1}$ developed for the on-line chemical reaction of acetaminophen were in the 479$556 \mathrm{mg}$ and $460-535 \mathrm{mg}$ range, respectively. There was no significant difference between these two methods at a particular dissolution time nor was there any significant effect of dissolution time.

Average values of the populations for the FI/FTIR method with detection at 1274.1 and $1498.2 \mathrm{~cm}^{-1}$ were 512 and $491 \mathrm{mg}$, respectively. The results obtained from the FTIR experiment are in good agreement with the nominal mass as specified by the manufacturer. In contrast, the FI/visible method gave an average value of $566 \mathrm{mg}$. This comparison suggests that the results in the visible region are too high, probably because of other materials in the formulation which absorbs at the same wavelength. The superior selectivity of the IR method is clearly evident in this situation.

The results confirmed the ability of the FI/FTIR technique to yield useful information for the spectrophotometric monitoring of chemical processes. The combination of FI/FTIR is particularly powerful and useful for studying systems involving on-line reaction products and for monitoring their FI transients. The greater selectivity of an infrared over a visible spectrophotometric procedure makes it an excellent choice for the identification of species in on-line reactions.

\section{References}

[1] M.K. Srivastava, S. Ahmad, D. Singh, I.C. Shukla, Analyst 110 (1985) 735.

[2] N. Jie, J. Yang, T. Liu, Talanta 41 (1994) 415.

[3] L. Chafetz, R.E. Daly, H. Schriftman, J.J. Lommer, J. Pharm. Sci. 60 (1971) 463.

[4] A.A. El Kheir, S. Belal, M. El Sadek, A. El Shanwani, Analyst 111 (1986) 319.

[5] D.R. Davis, A.G. Fogg, D. Thorburn Burns, J.S. Wragg, Analyst 99 (1974) 12. 
[6] C.T.H. Ellcock, A.G. Fogg, Analyst 100 (1975) 16.

[7] S. Belal, M.A-H. Elsayed, A. El Walily, H. Abdine, J. Pharm. Sci. 68 (1979) 750.

[8] S. Belal, A.A. El Kheir, A. El Shanwani, Analyst 110 (1985) 205.

[9] D. Howie, P.I. Adriaenssens, L.F. Prescott, J. Pharm. Pharm. 29 (1977) 235.

[10] R.E. Chambers, K. Jones, Ann. Clin. Biochem. 13 (1976) 433.

[11] P.I. Adriaenssens, L.F. Prescott, Brit. J. Clin. Pharm. 6 (1978) 87.

[12] M.J. Stewart, P.I. Adriaenssens, D.R. Jarvie, L.F. Prescott, Ann. Clin. Biochem. 16 (1979) 89.

[13] A.N. Papas, M.Y. Alpert, S.M. Marchese, J.W. Fitzgerald, Anal. Chem. 57 (1985) 1408.

[14] R.M. Welch, A.H. Conney, Clin. Chem. 11 (1965) 1064.

[15] F.M. Plakogiannis, A.M. Saad, J. Pharm. Sci. 64 (1975) 1547.

[16] E. Kalatzis, I. Zarbi, J. Pharm. Sci. 65 (1976) 71.

[17] S. Belal, M.A-H. Elsayed, A. El Walily, H. Abdine, Analyst 104 (1979) 919.

[18] S.M. Sultan, I.Z. Alzamil, A.M. Aziz Alrahman, S.A. Altamrah, Y. Asha, Analyst 111 (1986) 919.

[19] M. Sultan, Talanta 34 (1987) 605.

[20] R.M. Riggin, A.L. Schmidt, P.T. Kissinger, J. Pharm. Sci. 64 (1975) 680.

[21] D.J. Miner, P.T. Kissinger, Biochem. Pharm. 28 (1979) 3285.

[22] D.J. Miner, J.R. Rice, R.M. Riggin, P.T. Kissinger, Anal. Chem. 53 (1981) 2258.

[23] J. Zhou, E. Wang, Anal. Chim. Acta 236 (1990) 293.

[24] W. Peng, T. Li, H. Li, E. Wang, Anal. Chim. Acta 298 (1994) 415.

[25] J. Wang, L.D. Hutchins, Anal. Chem. 57 (1985) 1536.

[26] J. Wang, T. Golden, P. Tuzhi, Anal. Chem. 59 (1987) 740.

[27] J. Wang, J. Liu, Anal. Chim. Acta 294 (1994) 201.

[28] K.K. Verma, A. Jain, K.K. Stewart, Anal. Chim. Acta 261 (1992) 261.

[29] J. Martínez Calatayud, M.C. Pascual Martí, S. Sagrado Vives, Anal. Lett. 19 (1986) 2023.

[30] J. Martínez Calatayud, S. Sagrado Vives, J. Pharm. Biomed. Anal. 7 (1989) 1165.

[31] D.K. Morgan, N.D. Danielson, J.E. Katon, Anal. Lett. 18 (1985) 1979.
[32] B.E. Miller, N.D. Danielson, J.E. Katon, Appl. Spectrosc. 42 (1988) 401

[33] E. Rosenberg, R. Kellner, Vib. Spec. 5 (1993) 33.

[34] E. Rosenberg, R. Kellner, J. Mol. Struc. 294 (1993) 9.

[35] E. Rosenberg, R. Kellner, Fresenius J. Anal. Chem. 348 (1994) 530.

[36] M. Guzmán, J. Ruzicka, G.D. Christian, P. Shelley, Vib. Spec. 2 (1991) 1.

[37] M. de la Guardia, S. Garrigues, M. Gallignani, J.L. Burguera, M. Burguera, Anal. Chim. Acta 261 (1992) 53.

[38] S. Garrigues, M. Gallignani, M. de la Guardia, Analyst 117 (1992) 1849.

[39] S. Garrigues, M. Gallignani, M. de la Guardia, Talanta 40 (1993) 89.

[40] M. Gallignani, S. Garrigues, M. de la Guardia, Anal. Chim. Acta 274 (1993) 267.

[41] M. de la Guardia, M. Gallignani, S. Garrigues, Anal. Chim. Acta 282 (1993) 543.

[42] M. Gallignani, S. Garrigues, A. Martínez-Vado, M. de la Guardia, Analyst 118 (1993) 1043.

[43] M. Gallignani, S. Garrigues, M. de la Guardia, Analyst 119 (1994) 653.

[44] W.G. Collier, D.J. Curran, Anal. Chim. Acta 177 (1988) 259.

[45] M. Gallignani, S. Garrigues, M. de la Guardia, Analyst 119 (1994) 1773.

[46] M.L. Ramos, J.F. Tyson, D.J. Curran, Anal. Proc. 32 (1995) 175.

[47] P.T. McKittrick, N.D. Danielson, J.E. Katon, J. Liquid Chrom. 14 (1991) 377.

[48] P.T. McKittrick, N.D. Danielson, J.E. Katon, Microchem. J. 44 (1991) 105.

[49] K.D. Khalaf, B.A. Hasan, A. Morales-Rubio, M. de la Guardia, Talanta 41 (1994) 547.

[50] W.D. Perkins, Sample Handling in Infrared Spectroscopy An Overview, in P.B. Coleman (Ed.), Practical Sampling Techniques for Infrared Analysis, CRC Press Inc., Boca Raton, Florida, 1993, p. 26.

[51] E.D. Becker, H. Ziffer, E. Charney, Spectrochim. Acta 19 (1963) 1871.

[52] J. C. Miller, J. N. Miller, Statistics for Analytical Chemists, 2nd edn., Ellis Horwood, Chichester, UK, 1988, pp. 112-113. 